HUNGARIAN AGRICULTURAL ENGINEERING

$N^{\circ} 37 / 2020$ 80-89

Published online: http://hae-journals.org/

HU ISSN 0864-7410 (Print) / HU ISSN 2415-9751(Online)

DOI: 10.17676/HAE.2020.37.80

Received: 10.11.2019 - Accepted: 02.03.2020
PERIODICAL OF THE COMITTEE OF

AGRICULTURAL AND BIOSYSTEM

ENGINEERING OF

THE HUNGARIAN ACADEMY OF SCIENCES

and

SZENT ISTVÁN UNIVERSITY

Faculty of Mechanical Engineering

\title{
MODELLING WATER PRODUCTIVITY OF SELECTED GRAIN CROPS IN RAIN-FED AND SURFACE IRRIGATED FIELDS IN NORTHERN NIGERIA.
}

Author(s):

A. Sobowale ${ }^{1}$, A.A. Ramalan², O.J. Mudiare², M.A. Oyebode ${ }^{2}$

\author{
Affiliation: \\ 1Department of Agricultural and Bioresources Engineering, \\ Federal University of Agriculture, PMB 2240 Abeokuta 110001, Nigeria. \\ ${ }^{2}$ Department of Agricultural Engineering, Ahmadu Bello University, Zaria, Nigeria \\ Email address: \\ Sobowalea@funaab.edu.ng
}

\begin{abstract}
Field trials of selected grain crops (rice, wheat and maize) were conducted for three years under rain-fed and surface irrigated systems to evaluate their water productivity and model same. A completely randomized design (CRD) experiment was used at the Irrigation Research Station, Kadawa, Kano State. Rice yield was 11.6, 9.9 and 5.3 tons/ha; wheat yield was $1.46,1.92$ and 2.0 tons/ha, while Maize yield was 0.8 , 0.4 and 0.91 tons/ha in the 2009/2010,2010/2011 and 2011/2012 cropping season, respectively. ANOVA revealed a highly significant difference in the yield of paddy rice, wheat and maize at both $1 \%$ and $5 \%$ significant levels (Fcalc $>$ Ftab), with p-value of $0.0002,0.004$ and 0.001 for rice, wheat and maize respectively. Crop - water productivity models developed revealed that optimum crop yield of 12.8 tons/ha of paddy rice, 2.7 tons $/$ ha of wheat and 0.94 tons $/$ ha of maize is achievable with $58.3 \mathrm{~cm}$ of rainfall, $34 \mathrm{~cm}$ and of $29.8 \mathrm{~cm}$ of irrigation water respectively.
\end{abstract}

Keywords: Water, Crop yield, Productivity, Irrigation, Food security

\section{Introduction}

Attaining food security is an important endeavour that every developing countries especially in sub-Saharan Africa (SSA) must commit to in order to avert future crisis. According to [9], increasing agricultural productivity is very important to food security in the following ways: it produces the food people eat; and it provides the primary source of livelihood for $36 \%$ of the world's total workforce. In the heavily populated countries of Asia and the Pacific, this share ranges from 40 to $50 \%$, and in SSA, two-thirds of the working population still make their living from agriculture [15]. The dominant crop production system in SSA is the rain-fed agricultural system; this cannot guarantee the much needed sufficiency in food production. [5] opined that effective food security can only be achieved through irrigated agriculture; this is possible because irrigation ensures all year round food production within the limits of the available water resources. They further argued that irrigation accounts for about $72 \%$ of global and $90 \%$ of developing - country water withdrawals; and water availability for irrigation may have to be reduced in many regions in favour of rapidly increasing nonagricultural water uses in industry and households, as well as for environmental sustainability.

In SSA, irrigation development is presently low despite the huge potential that exists. In Nigeria, for example, the country has over 74 million hectares of arable land, good for farming; current reliable data shows that only about $0.3 \%$ of this land area is currently developed and equipped for irrigation (FAOSTAT). The implication of these is that a huge potential exist for achieving food security in Nigeria. This scenario presents a great opportunity for Nigeria not to make the same mistakes other nations that invested massively in irrigated agriculture without adequate irrigation water management, especially with the climate change phenomenon in full swing in SSA.

[2] also posited that by 2050 , agriculture will need to produce $60 \%$ more food globally, and $100 \%$ more in developing countries; this will definitely exert pressures on the world's freshwater resources. Inefficient use of water for crop production has depleted aquifers, led to reduced river flows, degraded wildlife habitats, and has 
caused salinization of about $20 \%$ of the global irrigated land area [10]. According to [16], the quest for food security and improved access to water, have led to tremendous resources being invested in developing water for agricultural uses; but, with the growing demand for water for industry and municipalities, combined with environmental problems, there is bound to be less water for agriculture in the future. In order to avoid a crisis, it becomes imperative for developing nations to begin to plan their water management systems in such a way that all contending water uses will be sustainably catered for. One approach found in literature is increasing the productivity of water by ensuring that more crop is produced from every drop of water [18][14][22]; this will help avert water scarcity and free enough water for other competing needs, other approaches includes wastewater recycling and reuse, conjunctive use of surfacewater and groundwater and managed aquifer recharge [6] From the account of [18], Water Productivity (WP) can be defined as the ratio of net benefits from crop, forestry, fishery, livestock, and mixed agricultural systems to the amount of water required to produce those benefits; this imply a ratio of total weight of harvested crop or monetary value of proceeds to the amount of water used for its production. It is pertinent to point out that WP differ among crop types, production systems and agro-ecological zones. With growing irrigation-water demand and increasing competition across water-using sectors, the world now faces a challenge to produce more food with less water. This goal will be realistic only if appropriate strategies are found for water savings and for more efficient water uses in agriculture.

Several researches have been reported in literature on the subject of water productivity and food security [19][13][24][17][1][12] [11][23]; however, very little efforts have been reported in SSA, especially Nigeria. Water productivity research was pioneered in Nigeria by [14] with a study on onions; [3] investigated the water productivity of drip irrigated Soybeans; [22] also evaluated for rice under various irrigation schedules and tillage practices in Northern Guinea Savannah Region of Nigeria while [4] investigated the water productivity of Cassava under rain fed production system. All these studies have added to knowledge, however, more still need to be done in order to improve our production systems and to better adapt to the changing climate and manage agricultural water effectively. The aim of this research was to develop models for water productivity of selected grain crops in rain fed and surface irrigated systems as a decision support for agricultural planning for adaptation to the changing climate in Nigeria.

\section{Materials and Methods}

\section{Study location}

The research was carried out at the 26.9 ha Irrigation Research Station, Kadawa within the Kano River Irrigation Project (KRIP), Kano State, Nigeria. The station is located about $47 \mathrm{~km}$ south of the capital, Kano City between longitudes 8025.451 and 8026.151 E. and latitudes 11038.291 and 11038.501 N. The area is situated within the Sudan savannah agro-ecological zone of Nigeria; local climate indicate three distinct seasons; namely, wet season (early June - late September (4 months)), cool dry season (October - mid February ( $4 \frac{1}{2}$ months)) and hot dry season (mid-February - early June (31/2 months)). The mean annual rainfall range between $700-800 \mathrm{~mm}$, while mean daily temperature ranges from $29^{\circ} \mathrm{C}$ to $38^{\circ} \mathrm{C}$ [20]. KRIP is cited on a dissected peneplain developed on the crystalline Precambrian rocks of the basement complex, the main rock types are granite, gneisses and schist, complex glimmer schist and quartzite. The top of the basement complex is deeply weathered and soils of the experimental farm belong to the upland plain, about $60 \%$ are deep and well drained, and the remaining $40 \%$ are poorly drained and are underlain by an iron pan of Ferruginous Feldspar found at an average soil depth of $1.52 \mathrm{~m}$; the soils are mostly sandy loam textured top soil and sandy clay loam textured subsoil. The IRS experimental farmland is divided into four blocks namely: F-3.4, F-3.5, F-3.6 and F-3.7 as shown in figure 1 and intensively cropped with vegetables, wheat, onions, tomatoes, rice, etc. Each block was well laid out and generally slopes in the south easterly direction with water canals running along their northern side and drain on the south, the water canals run over a gradient and have several drop structures along their length to control the velocity of flowing water.

\section{Field Layout and Experimental Design}

The field trials were established on a 0.15 ha land in the F-3.4 block as shown in figure 1; plot size of $5 \mathrm{~m} \mathrm{x}$ $80 \mathrm{~m}$ divided into 16 basins of $5 \mathrm{~m} \times 5 \mathrm{~m}$ each was laid out in a completely randomized design (CRD) with 
three replicates to make a total of 48 basins as shown in figure 1, equal treatment was given to all the replicates in the trials; basin irrigation method was used for dry season cropping while, wet season cropping was rain fed. For the purpose of irrigation, a $75 \mathrm{~mm}$ internal diameter siphon tube was used to supply water to a $5 \mathrm{~m} \mathrm{x}$ $3 \mathrm{~m}$ buffer basin at the beginning of the plots to stabilize the flow before passing through cut - throat flumes (for measurement of irrigation depth) and into the experimental basins; the water was thereafter controlled to cascade from one basin to the other and no runoff was allowed out of the plots during irrigation, neither was cross flows allowed from adjoining plots; this was achieved by constructing dykes at the plot borders and ensuring that irrigation water was cut out after the 13th basin was satisfied, water continues to flow till the last basin was irrigated, this strategy ensured that the trials were not over irrigated. The cropping schedule for the three years of trials $(2009 / 2010,2010 / 2011$ and 2011/2012) is presented in Table 1.

\section{Cultural Practices}
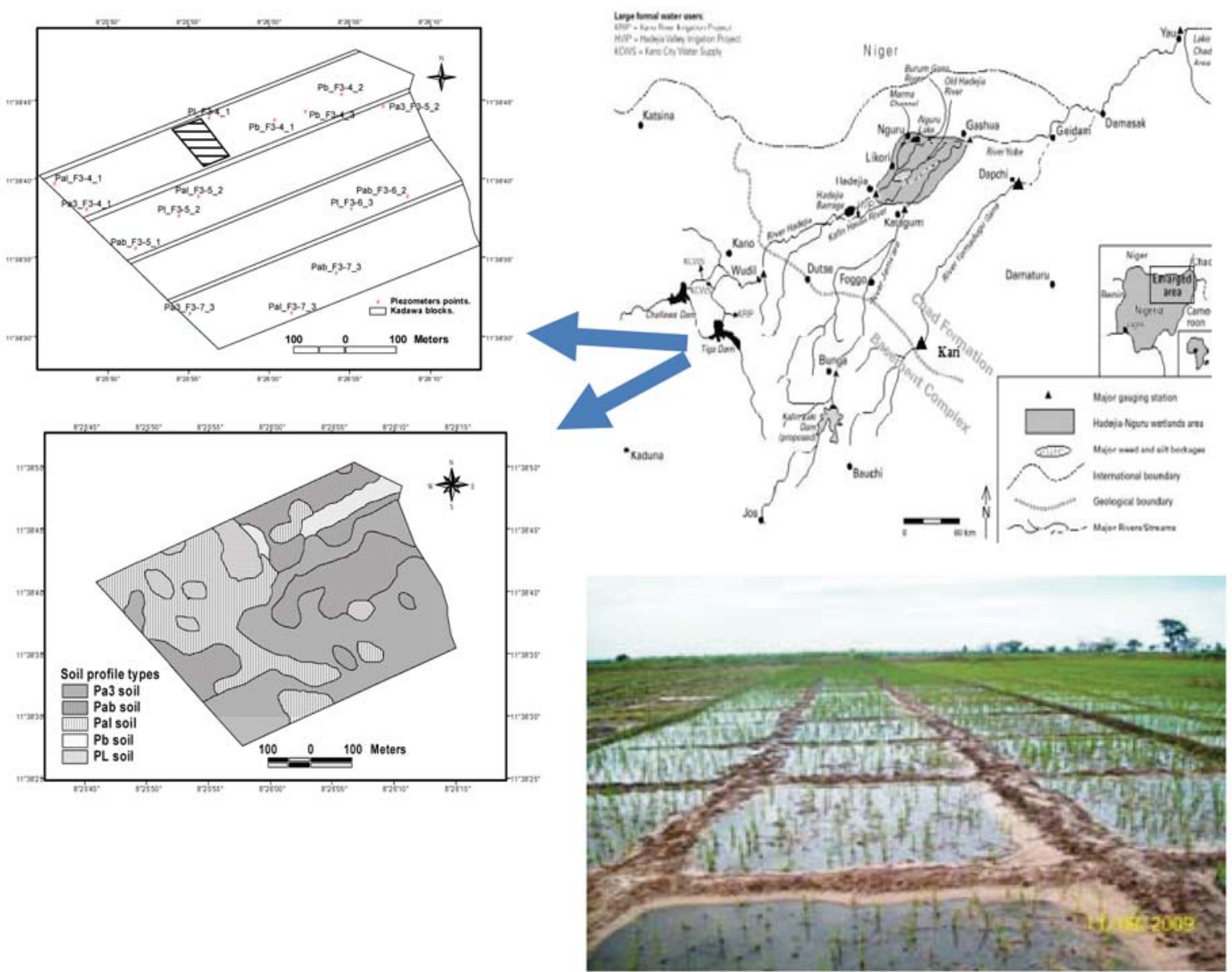

$80 \mathrm{~m}$

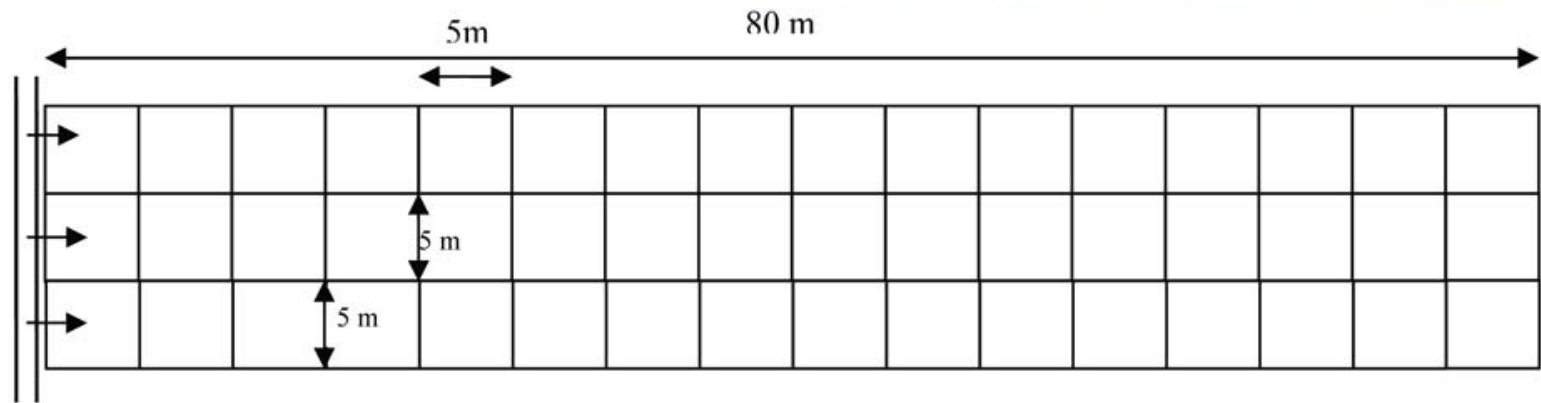

Figure 1. Location, soil classification, and experimental plot layout at the study site 
Table 1. Cropping schedule for field trials

\begin{tabular}{clcccc}
\hline Season & Period & Crop & $\begin{array}{c}\text { Botanical } \\
\text { Name }\end{array}$ & Cultivar & $\begin{array}{c}\text { Number } \\
\text { of Days }\end{array}$ \\
\hline Cool dry & Dec - March & Wheat & Triticum aestivum & SAM-WHIT-5 & 120 \\
Hot dry & April - July & Maize & $\begin{array}{c}\text { Zea mays } \\
\text { Sammaz 13 }\end{array}$ & 80 \\
Wet & August - Nov & Rice & Oryza sativa L & CP & 130 \\
\hline
\end{tabular}

The crops were cultivated in succession for the three years, wheat was planted using a seed rate of $100 \mathrm{~kg} / \mathrm{ha}$ and was sown by hand drilling at a row spacing of $20 \mathrm{~cm}$; rice was sown by broadcasting on a seed bed and then later transplanted to the basins using a row spacing of $20 \mathrm{~cm}$, while Maize, on the other hand was also planted manually using a row spacing of $30 \mathrm{~cm}$. Fertilizer application of $50 \mathrm{~kg} \mathrm{~N}, 50 \mathrm{~kg}$ P2O5 and $50 \mathrm{~kg} \mathrm{~K} 2 \mathrm{O}$ /ha in the form of NPK 15: 15: 15 was given at planting while $50 \mathrm{~kg} \mathrm{~N} / \mathrm{ha}$ was applied in the form of Urea $(46 \% \mathrm{~N})$ at four weeks after planting by top dressing. Pre and post emergence herbicides were applied to the field as at when due, this was also supplemented with manual weeding to remove weeds; this same process applies to maize and rice cropping. The rice specie cultivated was lowland rice since the areas is completely waterlogged in the raining season. Day guards were employed to wade off birds manually when necessary. It should be noted that the use of basin to grow maize crop is not ideal for the area; however, it was needful to ensure uniformity in the planting method for the three years of study.

\section{Data Collection and Analysis}

Pertinent data collected during the trials includes irrigation water application depth, irrigation time, rainfall, temperature, relative humidity, solar radiation and crop yield. Evapotranspiration on the farmland was estimated using the Blaney-Morin-Nigeria (BMN) model developed on the farmland and crop coefficient factor Kc by [7]:

$$
E t_{o}=\frac{r_{f}(0.45 T+8)\left(520-R^{1.31}\right.}{100}
$$

where, $\mathrm{Et}_{\mathrm{o}}=$ potential evapotranspiration,

$\mathrm{r}_{\mathrm{f}}=$ ratio of maximum possible radiation to the annual maximum, $\mathrm{T}=$ Mean temperature $\left({ }^{\circ} \mathrm{C}\right)$, and $\mathrm{R}=$ Relative humidity $(\%)$.

$$
E t_{c}=E t_{o} * k_{c}
$$

where Etc $=$ crop evapotranspiration and $\mathrm{kc}=$ crop coefficient (for maize $\sim 0.84$, wheat $\sim 0.675$, and rice $\sim$ 1). Daily crop evapotranspiration data was used to design for appropriate irrigation water application depth for each crop. The data collected were analysed using R statistical software to obtain pertinent descriptive and inferential statistics; regression analysis was used to develop crop yield models using irrigation and rainfall depths for the three seasons identified in the area.

\section{Result and Discussion}

\section{Rainfall and Temperature Distribution}

Rainfall during the trial period followed a similar pattern with what obtains in the agro-ecological zone, the onset of the rains fell majorly in the month of June except for year 2010, when it occurred in the month of May. The Cessation of the rains took place in October for the year 2009 and 2010 while it occurred earlier in September of year 2011. The total amount of rainfall received annually for the three years of study range from $29.0-77.5 \mathrm{~cm}$, year 2011 was a drought year having the lowest amount of annual rainfall in the study period, 
thus requiring supplemental irrigation in the wet season; this has direct implication for yield of crops in the area. Figure 2 shows the trend of daily temperature all through the three years of the study. Daily temperature in the period was lowest at $16^{\circ} \mathrm{C}$ and occurred on $17^{\text {th }}, 21^{\text {st }}, 22^{\text {nd }}$, and $23^{\text {rd }}$ of November 2009 , while the highest temperature in the period was $42^{\circ} \mathrm{C}$ and occurred on $8^{\text {th }}$ of April 2012. Total irrigation water applied annually range between 65.4 and $91.5 \mathrm{~cm}$ from $2009-2011$.

\section{Yield of Selected Crops}

Table 2 presents the yield and the analysis of variance (ANOVA) results for the selected crops in the three years of study; rice yield was 11.6, 9.9 and 5.3 tons/ha in 2009/2010, 2010/2011 and 2011/2012 cropping year respectively. The lower value obtained in the 2011/2012 season was directly linked to the low rainfall in the period, the farmers generally experienced very low harvest of paddy rice in the entire irrigation scheme. ANOVA revealed a highly significant difference in the yield of paddy rice at both $1 \%$ and $5 \%$ significant levels (Fcalc $>$ Ftab), this was further confirmed by a p-value of 0.0002. According to [21], the average world yield for paddy rice was 4.3 tons/ha (1961-2009) while the Nigerian average production figure was 1.01 tons/ha; the results obtained from the field trials are novel indeed despite the limitation of climate change, the result is a pointer that Nigeria can achieve more productivity and food security with paddy rice production, but irrespective of this outcome, more cultivars of rice presently grown in Nigeria need to be tested using basin irrigation. It should be noted that the more the lowland rice is submerged in water, the more its productivity [24]. The dykes constructed to prevent runoff from the plots were very effective leading to maximum water availability for crop growth and development. The average yield was found to be above the world average by $62.3 \%$.
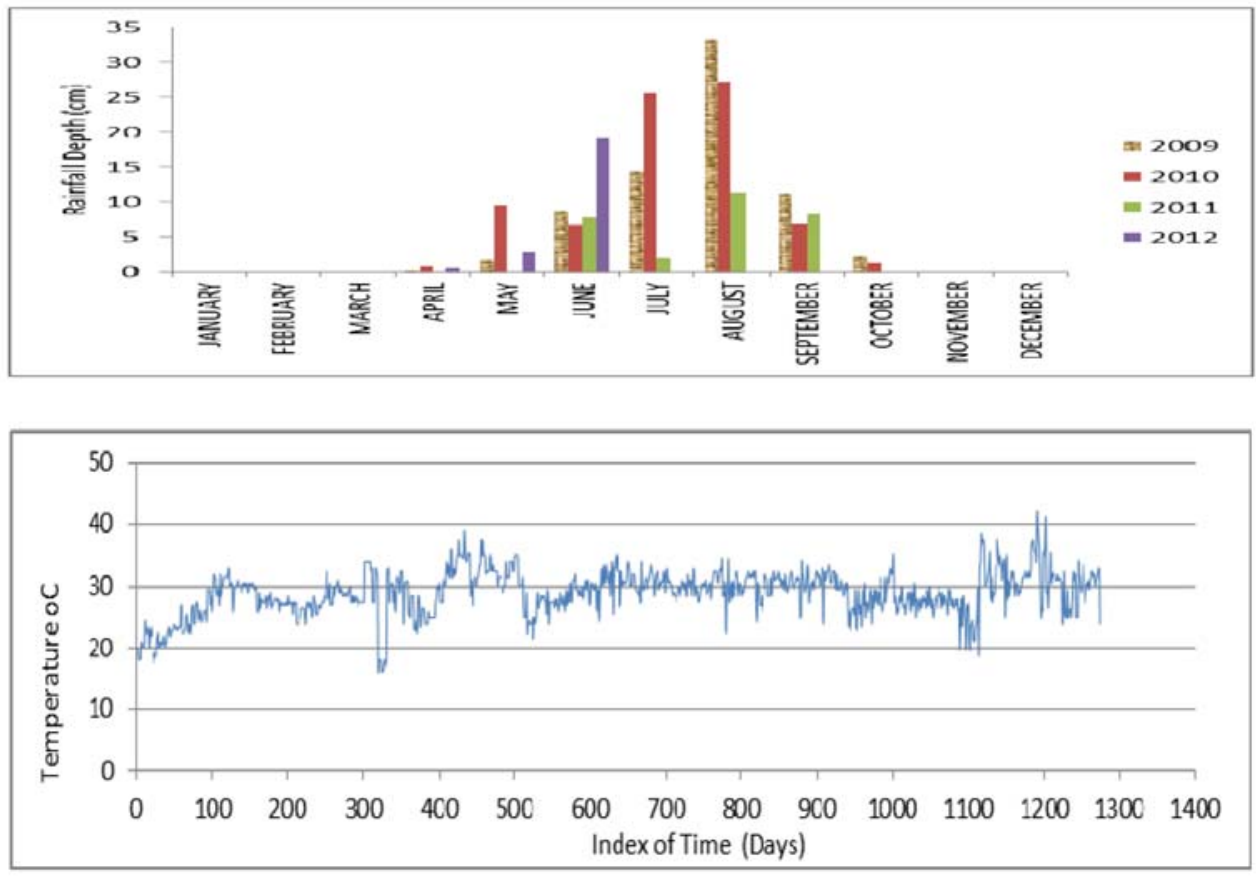

Figure 2. Rainfall and Temperature distribution during the study (2009-2012)

Wheat trials using basin irrigation method in the cool dry season took place between the month of December and March/April (depending on the sowing date), this in contrast to what obtains in the area in the past, sowing in December was due to the change in the arrival time of the North East trade winds responsible for the harmattan winter season. This is an evident impact of climate change on crop production systems in the area. The yield data of the three years of wheat cropping is presented in Table 2. The average yield obtained during the trials was 1.46, 1.92 and 2.0 tons/ha in the 2009/2010, 2010/2011 and 2011/2012 cropping season, 
respectively. These values were generally lower than the world average of 3.1 tons/ha (1961-2009), but are higher than the Nigerian average wheat production figures of 1.1 tons/ha. ANOVA revealed a highly significant difference in the yield of wheat at both $1 \%$ and $5 \%$ significant levels (Fcalc $>$ Ftab), this was further confirmed by a very low p-value of 0.004 . Nigeria is not an important wheat producer; the entire wheat crops produced are consumed locally. Averagely, the harvests were good owing to the proper water management on the experimental plots. Field observations showed that the yield was better than the ones obtained by local farmers in the area due to over-irrigation. Farmers in the area practice wild flooding without any water management, forgetting that the wheat crop is not as water loving as rice; the rather poor yield obtained by farmers was found to be responsible for many of them shying away from planting wheat but prefer to plant tomatoes and onions in the cool dry season.

Table 2. Variability of yield and water productivity of selected crops $(2009-2012)$

\begin{tabular}{|c|c|c|c|c|c|c|}
\hline \multicolumn{3}{|l|}{ Rice } & & & & \\
\hline Years & $\begin{array}{c}\text { Yield } \\
\text { (tons/ha) }\end{array}$ & $\begin{array}{c}\text { Water } \\
\text { Productivity } \\
\text { (ton } / \mathrm{ha} / \mathrm{cm} \text { ) }\end{array}$ & & & & \\
\hline $2009 / 2010$ & 11.6 & 0.16 & & & & \\
\hline $2010 / 2011$ & 9.9 & 0.13 & & & & \\
\hline $2011 / 2012$ & 5.3 & 0.18 & & & & \\
\hline Source of Variation & SS & $d f$ & MS & $F$ & $P$-value & F crit \\
\hline Between Years & 64.7 & 2.0 & 32.3 & 46.935 & 0.0002 & 5.143 \\
\hline Within Years & 4.1 & 6.0 & 0.7 & & & \\
\hline Total & 68.8 & 8 & & & & \\
\hline \multicolumn{3}{|l|}{ Wheat } & & & & \\
\hline Years & $\begin{array}{c}\text { Yield } \\
\text { (tons/ha) }\end{array}$ & $\begin{array}{c}\text { Water } \\
\text { Productivity } \\
\text { (ton/ha/cm) }\end{array}$ & & & & \\
\hline $2009 / 2010$ & 1.5 & 0.03 & & & & \\
\hline $2010 / 2011$ & 1.9 & 0.08 & & & & \\
\hline $2011 / 2012$ & 2.0 & 0.05 & & & & \\
\hline Source of Variation & SS & $D f$ & MS & $F$ & P-value & F crit \\
\hline Between Years & 0.6 & 2 & 0.28 & 16.18 & 0.004 & 5.14 \\
\hline Within Years & 0.1 & 6 & 0.02 & & & \\
\hline Total & 0.7 & 8 & & & & \\
\hline \multicolumn{3}{|l|}{ Maize } & & & & \\
\hline Years & $\begin{array}{c}\text { Yield } \\
\text { (tons/ha) }\end{array}$ & $\begin{array}{c}\text { Water } \\
\text { Productivity } \\
\text { (ton } / \mathrm{ha} / \mathrm{cm} \text { ) }\end{array}$ & & & & \\
\hline $2009 / 2010$ & 0.83 & 0.03 & & & & \\
\hline $2010 / 2011$ & 0.37 & 0.02 & & & & \\
\hline $2011 / 2012$ & 0.93 & 0.03 & & & & \\
\hline Source of Variation & SS & $d f$ & MS & $F$ & P-value & F crit \\
\hline Between Years & 0.55 & 2 & 0.27 & 27.4 & 0.001 & 5.1 \\
\hline Within Years & 0.06 & 6 & 0.01 & & & \\
\hline Total & 0.61 & 8 & & & & \\
\hline
\end{tabular}

Maize traditionally is planted in ridges in the area, but because of the need to maintain uniformity in the production system, basin irrigation method was used. Yield data of $0.8,0.4$ and 0.91 tons/ha were obtained in the 2009/2010,2010/2011 and 2011/2012 cropping season, respectively. This was found to be lower than the world average of 5.3 tons/ha, it should however be noted that the yield figures given here are for dried shelled grains. The yield obtained in the 2011/2012 year was just slightly lower than the Nigeria average. The generally low yield in the first and second year could be adduced to the planting of the maize in basins rather 
than ridges. The yield however increased when planted on ridges in the third year. This confirms that the method of seed bed preparation has a great influence on crop productivity. ANOVA revealed a highly significant difference in the yield at both $1 \%$ and $5 \%$ significant levels (Fcalc $>$ Ftab), this was further confirmed by a low p-value of 0.001 .

Understanding the relationship between crop yield and water utilization is very important for planning of irrigation water and management of available water resources [25]; Table 3 presents the crop-water models developed from the crop yield and water use data obtained from the three years of trials. The regression models reveals an excellent relationship between the two variables and are useful for planning rain-fed cropping of rice and irrigation planning for wheat and maize in the area.
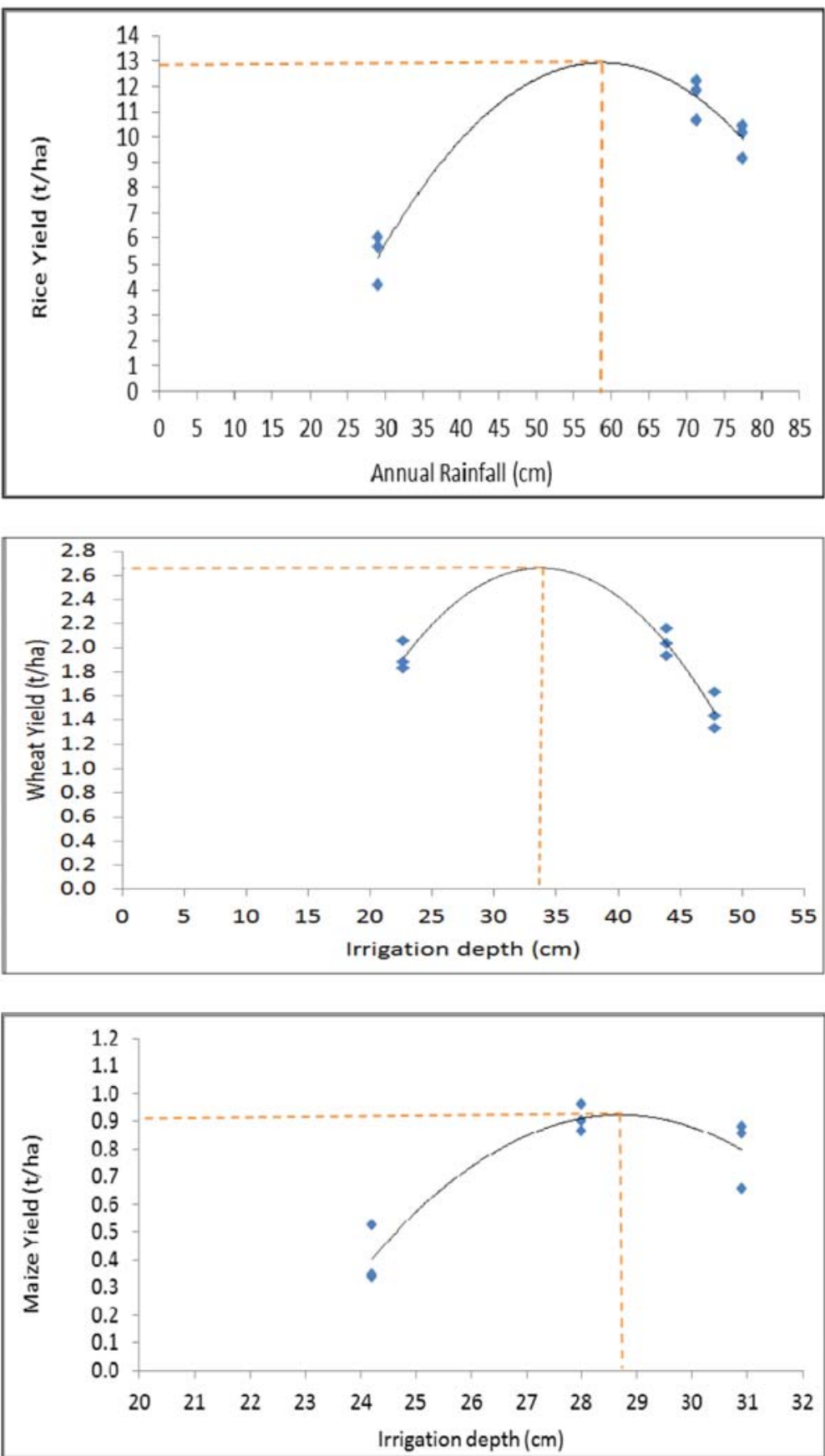

Figure 3. Simulation of crop yield as a function of rainfall and irrigation depth (2009-2012) 
Table 3. Crop Water productivity models of selected crops

\begin{tabular}{lcc}
\hline \multicolumn{1}{c}{ Crop/Cultivar } & Model & $\mathbf{R}^{2}$ \\
\hline Rice (cp) & $y=-0.0087 x^{2}+1.0177 x-16.978$ & 0.9399 \\
Wheat (SAM-WHIT-5) & $y=-0.0061 x^{2}+0.412 x-4.2912$ & 0.8452 \\
Maize (Sammaz 13) & $y=-0.0026 x^{2}+1.4702 x-20.175$ & 0.8801 \\
\hline Key: $\mathrm{y}=$ yield (tons/ha), $x$ = Irrigation depth in cm for wheat and maize, but rainfall for rice
\end{tabular}

Figure 3 shows the yield curves generated from the models for rice, wheat and maize respectively. Pertinent information obtained from the analysis is the optimum yield of the crops possible in the area and the rainfall and irrigation water amount that can deliver such yield, all things being equal.

In view of the prevailing environmental conditions, the models can be used to predict the yield of rice on the farmland provided the agronomic practices and land preparations are the same. Further analysis show that optimum crops yield of 12.8 tons/ha of paddy rice is achievable with $58.3 \mathrm{~cm}$ of rainfall in the area; this imply that the 70 $80 \mathrm{~cm}$ of rainfall received in the area annually can adequately support rice cultivation in the area. Likewise for wheat, an optimum yield of 2.7 tons/ha can be achieved with $34 \mathrm{~cm}$ of irrigation water application all things being equal. This implies that more crop yield can be achieved with less water in the area. Literature shows that winter wheat does not require more than $4-5$ irrigation cycles from sowing to maturity depending on climate and length of the growing period [8]. The model also revealed that optimum crop yield of $0.94 \mathrm{t} / \mathrm{ha}$ of maize is achievable with irrigation water application of $28.8 \mathrm{~cm}$ all things being equal. The above results indicate that higher productivity is possible with appropriate amount of water application for each crop; this has profound implication for food security in the area and improved income and livelihood for smallholder farmers which constitute the largest percentage of farmers in SSA. It is however, pertinent to state that the crop yield models developed for these crops are not conclusive as further studies still need to be carried out to appropriately verify them using various levels of the model variables and other cultivars of the selected crops. However, for rough estimations, the models can be used.

\section{Conclusion}

The research focussed on the development of water productivity models for rice, wheat and maize in rain-fed and surface irrigated fields in the most active irrigation scheme in Nigeria. The results of the field trials indicate that appreciable yield of the crops is feasible within the limits of the changing climate in the area. The southern shift of the Sahara notwithstanding, food security can be achieved with adequate water management strategies in place; the water productivity models developed revealed that an optimum crop yield of 12.8 tons/ha of paddy rice, 2.7 tons/ha of wheat and 0.94 tons/ha of shelled maize is achievable with $58.3 \mathrm{~cm}$ of rainfall, $34 \mathrm{~cm}$ and of $29.8 \mathrm{~cm}$ of irrigation water respectively. The study revealed that poor irrigation water management is largely responsible for the low yield of crops from farmer's field in the area. This brings to the fore the need to revamp irrigation extension services in the area; many of the farmers practice wild flooding which and they lack basic information about crop water requirement. The outcome of this present study is an important decision support for agricultural planning in the area. Further studies are however required particularly for other crops of economic importance to the region.

\section{Acknowledgement}

The authors acknowledge the support of Institute of Agricultural Research, Samaru, Zaria for granting access to use the facilities at the Irrigation Research Station, Kadawa, Kano State. Special thanks to Messrs Jeremiah Wuya, Eddy Ezekiel and Mr John Olaleye of Agronomy Department, Ahmadu Bello University, Zaria, Nigeria for their invaluable assistance during the trials.

\section{References}

[1] Ali M.H. and Talukder M.S.U. (2008). Increasing water productivity in crop production - A synthesis, Agricultural Water Management, 95(11): 201-1213. https://doi.org/10.1016/j.agwat.2008.06.008 
[2] Alexandratos, N. and Bruinsma, J. (2012). World agriculture towards 2030/2050: The 2012 revision. ESA Working Paper No. 12-03. Rome, Food and Agriculture Organization of the United Nations (FAO). https://ageconsearch.umn.edu/record/288998

[3] Adeboye, O.B., Schultz, B., Adekalu, K.O. et al. Crop water productivity and economic evaluation of drip-irrigated soybeans (Glyxine max L. Merr.). Agric and Food Secur 4, 10 (2015).

https://doi.org/10.1186/s40066-015-0030-8

[4] Aderemi A. M., T. A. Ewemoje, J. O. Adedipe, I. O. Oyewo and L. A. Balogun (2018). Determination of Water Productivity of Cassava in Ibadan, South Western Nigeria. Arid Zone Journal of Engineering, Technology and Environment, 14(4): 237-246

[5] Cai X. and Rosegrant M.W. (2003) World Water Productivity: Current Situation and Future Options in J.W. Kijne, R. Barker and D. Molden (eds), Water Productivity in Agriculture: Limits and Opportunities for Improvement. CAB International, p 163-178. https://publications.iwmi.org/pdf/H032641.pdf

[6] Cosgrove, W. J., and D. P. Loucks (2015), Water management: Current and future challenges and research directions, Water Resour. Res., 51, 4823-4839,

doi:10.1002/ 2014WR016869. https://agupubs.onlinelibrary.wiley.com/doi/epdf/10.1002/2014WR016869

[7] Doorenbos, J. and Kasssam, A.H. 1979. Yield response to Water. FAO Irrigation and Drainage Paper No. 33. Rome, FAO. http://www.fao.org/3/a-i2800e.pdf

[8] Falaki, A. M. and I. B. Mohammed (2011). Performance of Some Durum Wheat Varieties at Kadawa, Kano State of Nigeria, Bayero Journal of Pure and Applied Sciences, 4(1): 48 - 51

https://www.ajol.info/index.php/bajopas/article/view/67924

[9] FAO (2008) Climate Change and Food Security: A framework Document. Food and Agricultural Organization, Rome, Italy. pp 97.

[10] FAO (2011). The State of the World's Land and Water Resources for Food and Agriculture: Managing systems at risk. London/Rome, Earthscan/FAO. http://www.fao.org/docrep/017/i1688e/i1688e.pdf

[11] Fraiture C., D. Molden, D. Wichelns (2010). Investing in water for food, ecosystems, and livelihoods: An overview of the comprehensive assessment of water management in agriculture. Agricultural Water Management 97: 495-501. https://www.sciencedirect.com/science/article/abs/pii/S0378377409002388

[12] Geerts S. and Raes D. (2009). Deficit irrigation as an on-farm strategy to maximize crop water productivity in dry areas, Agricultural Water Management, 96(9): 1275-1284.

https://doi.org/10.1016/j.agwat.2009.04.009

[13] Hamdy A., Ragab R. and Scarascia- Mugnozza E. (2003). Coping with water scarcity: water saving and increasing water productivity, Irrigation and Drainage, 52(1): 3-20 https://doi.org/10.1002/ird.73

[14] Igbadun, H.E., Ramalan, A.A. and Oiganji E. (2012), Effects of regulated deficit irrigation and mulch on yield, water use and crop water productivity of onion in Samaru, Nigeria. Agric. Water Manag., 109: 162169 https://www.sciencedirect.com/science/article/abs/pii/S0378377412000923

[15] ILO (2007) Key indicators of the labour market, 5th edition. International Labour organization http://www.ilo.org/public/english/employment/strat/kilm/download/kilm04.pdf

[16] Kijne, J. W., Barker R. and Molden D. (2003). Improving Water Productivity in Agriculture: Editors' Overview in J.W. Kijne, R. Barker and D. Molden edited, Water Productivity in Agriculture: Limits and Opportunities for Improvement. CAB International

http://www.iwmi.cgiar.org/Publications/CABI_Publications/CA_CABI_Series/Water_Productivity/Unprotect ed/0851996698toc.htm

[17] Liu J., Williams J. R., Zehnder A.J.B. and Yang H. (2007). GEPIC - modelling wheat yield and crop water productivity with high resolution on a global scale, Agricultural Systems, 94(2): 478-493. https://doi.org/10.1016/j.agsy.2006.11.019

[18] Molden, D., Frenken, K., Barker, R., de Fraiture, C., Mati, B., Svendsen, M., Sadoff, C., Finlayson, C.M. (2007). Trends in water and agricultural development. In: Molden, D. (Ed.), Water for Food, Water for Life: A Comprehensive Assessment of Water Management in Agriculture. Earthscan, London and International Water Management Institute, Colombo https://www.iwmi.cgiar.org/assessment/files_new/synthesis/Summary_SynthesisBook.pdf 
[19] Renault D. and Wallenderb W.W (2000). Nutritional water productivity and diets. Agricultural Water Management, 45(3): 275-296 https://doi.org/10.1016/S0378-3774(99)00107-9

[20] Sobowale A, Ramalan A.A., Mudiare O.J. and Oyebode M.A (2015) Evaluation of chloride mass balance and recharge in agricultural lands in Nigeria, Agricultural Engineering International: CIGR Journal, 2015, 17(2): 11 - 22 http://www.cigrjournal.org/index.php/Ejounral/article/view/3213

[21] Steduto P., T.C. Hsiao, E. Fereres and D. Raes (2012). Crop yield response to water, FAO Irrigation and Drainage Paper 66, Food and Agriculture Organization of the United Nations, Rome, 2012.

http://www.fao.org/3/a-i2800e.pdf

[22] Timon F., I. Alhassan, M. M. Maunde and N. J. Simon (2015). Irrigation Water Productivity of Rice under Various Irrigation Schedules and Tillage Practices in Northern Guinea Savanna Region of Nigeria. Trends Journal of Sciences Research, 2(3): 110-116, http://www.tjsr.org/journal/index.php/tjsr/article/view/25 [23] Wichelns, D. (2014) Do Estimates of

Water Productivity Enhance Understanding of Farm-Level Water Management, Water, 6: 778-795. https://www.mdpi.com/2073-4441/6/4/778/pdf

[24] Wu X.H., Wang W., Yin C.M., Hou H.J., Xie K.J. (2017) Water consumption, grain yield, and water productivity in response to field water management in double rice systems in China. PLOS ONE 12(12): e0189280. https://doi.org/10.1371/journal.pone.0189280

[25] Zwart S.J and Bastiaanssen W.G.M. (2004). Review of measured crop water productivity values for irrigated wheat, rice, cotton and maize, Agricultural Water Management 69(2):115-133.

https://doi.org/10.1016/j.agwat.2004.04.007 